\title{
STABILITY OF BASALT-FIBRES REINFORCEMENT IN ALKALI-ACTIVATED SYSTEMS
}

\author{
STABILNOST OJAČITVE Z BAZALTNIMI VLAKNI V ALKALNO \\ AKTIVIRANIH SISTEMIH
}

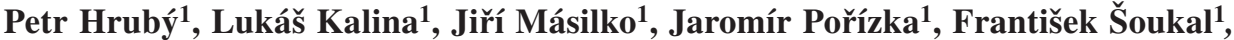 \\ Vlastimír Nevrlý ${ }^{2}$, Magdalena Kimm³ ${ }^{3}$, Thomas Gries ${ }^{3}$ \\ ${ }^{1}$ Brno University of Technology, Faculty of Chemistry, Purkyňova 118, 61200 Brno, Czech Republic \\ ${ }^{2}$ Brno University of Technology, Faculty of Mechanical Engineering, Technická 2896/2, 61200 Brno, Czech Republic \\ ${ }^{3}$ Institut für Textiltechnik (ITA) of RWTH Aachen University, Otto-Blumenthal-Straße 1, 52074 Aachen, Germany
}

Prejem rokopisa - received: 2019-07-15; sprejem za objavo - accepted for publication: 2019-11-26

doi:10.17222/mit. 2019.151

\begin{abstract}
Basalt fibres (BFs) represent suitable reinforcing materials for cementitious materials because of their mechanical and thermal properties as well as good price-performance ratio. The crucial issue limiting the possibility of using these fibres in alkali-activated systems (AASs) is their stability and durability in a highly alkaline environment. There is a significant inconsistency across the publications in this case. Hence, the verification of the BFs stability in an environment simulating the AAS is fundamental for a successful implementation as a reinforcement in the matrix. Accelerated leaching tests in water-glass $/ \mathrm{NaOH}$ and water-glass $/ \mathrm{Na}_{2} \mathrm{CO}_{3}$ solutions with the evaluation of loss of mass, loss of tensile strength as well as chemical composition changes of the fibres and leaching solutions were made using various techniques, such as XPS, SEM or ICP-OES. A noticeable loss of mass as well as a deterioration of the tensile properties accompanied by a simultaneous dissolution of the fibres was observed. Additionally, the transition-zone properties were studied using a SEM-EDX in this study. Poor or no adhesion between the BFs and the AAS matrix was found.
\end{abstract}

Keywords: alkali-activated materials, alkali resistance, basalt fibres, accelerated leaching tests, durability testing

Bazaltna vlakna (BF) so primerna ojačitev za cementne materiale, ker imajo dobre mehanske in termične lastnosti, kakor tudi ugodno razmerje med ceno in učinkovitostjo. Precejšnja omejitev je njihova uporaba $\mathrm{v}$ alkalno aktiviranih sistemih (AAS) ter njihova stabilnost in trajnost $v$ močno alkalnem okolju. V objavah na to temo najdemo številne neskladnosti. Zato je verifikacija stabilnosti bazaltnih vlaken v simuliranem AAS okolju osnova za njihovo uspešno uporabo, kot ojačitev alkalno aktivirane matrice. Avtorji so izvajali pospešene teste luženja v raztopinah: vodno steklo/ $\mathrm{NaOH}$ in vodno steklo/ $\mathrm{Na}_{2} \mathrm{CO}_{3}, \mathrm{z}$ ovrednotenjem izgube na masi, zmanjšanja natezne trdnosti in sprememb kemijske sestave vlaken. Mikrokemijske analize so izvajali z različnimi metodami, kot so: XPS, SEM in ICP-OES. Avtorji na osnovi preizkusov ugotavljajo pomembno raztapljanje vlaken in s tem povezano izgubo na masi, kot tudi istočasen padec natezne trdnosti. Dodatno so z uporabo SEM-EDX študirali lastnosti $\mathrm{v}$ prehodni coni vlaken. Našli niso nobene prave kohezijske vezi med bazaltnimi vlakni in AAS matrico.

Ključne besede: alkalno aktivirani materiali, odpornost proti alkalijam, bazaltna vlakna, pospešeni lužilni testi, preizkusi trajnosti

\section{INTRODUCTION}

The more widespread application potential of AAS could be supported by the utilization of fibre or fabric reinforcement since it is related with the improvement of mechanical properties along with ductility and overall durability. Besides favourable properties like earlier and higher initial mechanical strengths, lower hydration heat, better durability when exposed to high temperatures or aggressive environments they are also more environmentally friendly than $\mathrm{OPC}^{1}$, which is an important factor since the OPC production accounts for $7 \%$ of global $\mathrm{CO}_{2}$ production. ${ }^{2}$ The reduction in carbon dioxide emission of about $50 \%$ to $100 \%$ for one tonne of binder produced can be achieved by appropriately adjusting the composition of the AAS. ${ }^{3}$ One of the most common ways is the utilization of secondary raw materials like

*Corresponding author's e-mail: xchrubyp@fch.vut.cz (Petr Hrubý) blast furnace slag or various types of ashes from incineration.

Basalt fibres (BFs) represent suitable reinforcing materials for AAS because of their mechanical and thermal properties as well as a good price/properties' ratio, as stated in ${ }^{4-6}$. The crucial issue limiting the possibility of their utilization in AAS is their stability and durability in a highly alkaline environment. The superior durability of BFs was found under acid conditions in the studies. ${ }^{7,8}$ However, there is a significant inconsistency across the publications in the case of stability in a highly alkaline environment. Some of them ${ }^{4}$ stated good stability, meanwhile others like ${ }^{3,6-11}$ reported low stability when exposed to alkaline solutions. The dissolution process starts with the -Si-O-Si- and -Al-O-Si- bonds breakage and continues with dissolution through the pores and microcracks on the surfaces of the fibres..$^{10,11}$ As the dissolution of the aluminosilicate network occurs the gel layer is formed on the fibre surface and its thickness increases with time. Meanwhile, 


\section{P. HRUBÝ et al.: STABILITY OF BASALT-FIBRES REINFORCEMENT IN ALKALI-ACTIVATED SYSTEMS}

the dissolution reaction moves forwards to the fibre core, leaving insoluble oxides, hydroxo-carbonates and hydroxides as crystalline and amorphous phases behind. The formation of this phases retards further the diffusion rate of hydroxyl ions to the core of the fibre, as stated in ${ }^{8}$. The overall dissolution rate of the glassy structure may also be influenced by factors like the aqueous transport of chemical species in the near-surface region or the tendency to re-precipitate a solid if the equilibrium is approached, as described in $^{12}$. The dissolution process of BFs can be limited by the application of a proper surface coating, as reported $\mathrm{in}^{9,10}$. The mechanism of alkaliresistance improvement is related to the formation of a thin stable hydrated surface layer with a high content of, e.g., zirconium, which retards the hydroxide ions' diffusion rate. The formation of poorly soluble compounds containing $\mathrm{Mg}^{2+}, \mathrm{Ti}^{4+}$ or $\mathrm{Fe}^{3+}$ is responsible for the retardation of the dissolution process in the absence of $\mathrm{Zr}{ }^{10}$

\section{EXPERIMENTAL PART}

\subsection{Raw materials}

\subsubsection{Basalt fibres (BFs)}

The basalt fibres were provided by the Institut für Textiltechnik (ITA) of RWTH Aachen University. Table 1 describes the chemical composition of the BFs, originally from Kammeney Vek, determined by X-ray fluorescence (XRF). The amorphous structure of the BFs was confirmed using X-ray diffraction (XRD).

Table 1: Chemical composition of the BFs from Kammeney Vek determined by XRF analysis

\begin{tabular}{|c|c|c|c|c|c|c|c|c|}
\hline \multicolumn{1}{|c|}{ Chemical composition in $w / \%$} \\
\hline $\mathrm{SiO}_{2}$ & $\mathrm{Al}_{2} \mathrm{O}_{3}$ & $\mathrm{Fe}_{2} \mathrm{O}_{3}$ & $\mathrm{CaO}$ & $\mathrm{MgO}$ & $\mathrm{Na}_{2} \mathrm{O}$ & $\mathrm{K}_{2} \mathrm{O}$ & $\mathrm{TiO}_{2}$ & Other \\
\hline 55.7 & 15.4 & 10.8 & 7.4 & 4.1 & 2.4 & 1.5 & 1.2 & 1.4 \\
\hline
\end{tabular}

\subsubsection{Blast-furnace slag (BFS)}

Blast-furnace slag with a Blaine specific surface area of $400 \mathrm{~m}^{2} \cdot \mathrm{kg}^{-1}$ was obtained from Kotouč Štramberk, Ltd. Its chemical composition is given in Table 2. The BFS was $84 \%$ amorphous, while the rest was crystalline-akermanite $(9.5 \%)$; calcite $(3.7 \%)$; merwinite $(2.3 \%)$ and quartz $(0.5 \%)$ according to the XRD using the Rietveld method.

Table 2: Chemical composition of the BFS determined by X-ray fluorescence (XRF) analysis

\begin{tabular}{|c|c|c|c|c|c|c|c|c|c|}
\hline \multicolumn{10}{|c|}{ Chemical composition in $w / \%$} \\
\hline $\mathrm{CaO}$ & $\mathrm{SiO}_{2}$ & $\mathrm{MgO}$ & $\mathrm{Al}_{2} \mathrm{O}_{3}$ & $\mathrm{SO}_{3}$ & $\mathrm{TiO}_{2}$ & $\mathrm{~K}_{2} \mathrm{O}$ & $\mathrm{MnO}$ & $\mathrm{Na}_{2} \mathrm{O}$ & $\mathrm{Fe}_{2} \mathrm{O}_{3}$ \\
\hline 41.1 & 34.7 & 10.5 & 9.1 & 1.4 & 1.0 & 0.9 & 0.6 & 0.4 & 0.3 \\
\hline
\end{tabular}

\subsubsection{Alkaline activators}

Liquid sodium water-glass (WG) was obtained from Vodní sklo, Inc., silicate modulus $\left(M_{\mathrm{s}}\right)=2.24$; sodium hydroxide ( $\mathrm{SH}$ ) was obtained from PENTA Ltd. (pure); sodium carbonate (SC) was obtained from INCHEMA Ltd. (pure).

\subsection{Tests and methods}

\subsubsection{Accelerated leaching tests}

The accelerated leaching tests were designed to predict the long-term degradation behaviour of the BFs. The test is based on the immersion of specific BF fragments in various solutions at increased temperature $\left(60{ }^{\circ} \mathrm{C}\right)$ for a defined time period. The immersion solutions were designed with the goal to simulate the most aggressive environment formed in alkali-activated blast-furnace slag systems, thus the initial mixing solution (without BFs) where the concentration of alkalis as well as the $\mathrm{pH}$ is the highest. The summary of used solutions is as follows: WG/SC or WG/SH, $M_{\mathrm{s}}=0.5$; activator dosage $(6,8,10$ and 12$) \% \mathrm{Na}_{2} \mathrm{O}$; water-to-slag ratio $(w / s)=0.49$. The amount of solution was adjusted to the respective tests. The $\mathrm{pH}$ values of the immersion solutions were about 11.6 for WG/SC 6-12\% $\mathrm{Na}_{2} \mathrm{O}$ mixtures. The $\mathrm{pH}$ values of the $\mathrm{WG} / \mathrm{SH}$ solutions were slightly higher at 11.8-12.0 (the $\mathrm{pH}$ decreased with increasing activator dosage).

\subsection{Loss of mass}

The basalt fabric fragments with dimensions of about $2 \times 2 \mathrm{~cm}$ were prepared, weighed using an analytical balance and placed into polypropylene containers with a defined amount of immersion solutions, so the samples were immersed and covered with a $1-\mathrm{cm}$ layer above them. These containers were kept at $60{ }^{\circ} \mathrm{C}$. Three fragments were taken out in defined time intervals $(1,7,14,21$ and 28$) \mathrm{d}$, washed in distilled water for $24 \mathrm{~h}$ and then dried at $60{ }^{\circ} \mathrm{C}$ until the constant weight of the sample was reached. The loss of mass was determined as the percentage of the difference between the initial weight and the weight after leaching.

\subsection{Loss of tensile strength}

The leaching, washing and drying procedures were the same as in the previous case, but with a different sample size (bundle of filaments with length $35 \mathrm{~cm}$ ). The testing procedure was designed with reference to ASTM D2256. The tests were performed using the Zwick Z010 universal testing machine (deformation rate $5 \mathrm{~mm} / \mathrm{min}$; gauge length between jaws changed from $100 \mathrm{~mm}$ to $150 \mathrm{~mm}$ due to different disintegration of immersed testing samples). The clamps were pneumatic and designed for the fibres testing and originated from Zwick. The measured and evaluated parameter was the maximum strength before the fibre broke. The results are expressed as a percentage change against the reference (kept at $60{ }^{\circ} \mathrm{C}$ without immersion), thus as a tensile strength maintenance. 


\subsection{Chemical composition changes}

The chemical composition changes were studied on the fragments after the loss of mass testing and consisted mainly of XRD and XPS analyses, as will be specified more closely. The changes in the concentration of the selected elements ( $\mathrm{Al}, \mathrm{Fe}, \mathrm{Ca}$ and $\mathrm{Mg}$ ) in immersion solutions due to the fibres leaching were determined by means of the Inductively Coupled Plasma Optical Atomic Emission Spectroscopy (ICP-OES) - Horiba scientific Ultima 2. A defined amount of immersion solutions was taken in the time intervals of $(1,7,14,21,28,56$ and 84) $d$ of leaching, filtered through the $0.45-\mu \mathrm{m}$ syringe filter and 500-times diluted with distilled water.

\subsection{X-ray photoelectron spectroscopy and X-ray dif- fraction}

The XPS analyses were carried out with an Axis Ultra DLD spectrometer using a monochromatic Al- $K_{\alpha}$ $(\mathrm{h} v=1486.7 \mathrm{eV}) \mathrm{X}$-ray source operating at $75 \mathrm{~W}(5 \mathrm{~mA}$, $15 \mathrm{kV}$ ). The spectra were obtained using an analysis area of approximately $300 \times 700 \mu \mathrm{m}$. The Kratos charge neutralizer system was used for all the analyses. The high-resolution spectrum was measured with a step size $0.1 \mathrm{eV}$ and a pass energy of $20 \mathrm{eV}$. The instrument base pressure was $2 \cdot 10^{-8} \mathrm{~Pa}$. The spectra were analysed using CasaXPS software and charge corrected to the main line of the carbon $\mathrm{C} 1 \mathrm{~s}$ spectral component $(\mathrm{C} \backslash \mathrm{C} ; \mathrm{C} \backslash \mathrm{H})$ set to $284.80 \mathrm{eV}$. A standard Shirley background was used for all the sample spectra. The XPS measurements were made with the goal to characterize the changes of the BF surface layer due to the immersion in alkaline solutions.

The XRD analyses were carried out with a diffractometer Empyrean from the PANalytical corporation. The measurement parameters were as follows: tube current $30 \mathrm{~mA}$ and voltage $40 \mathrm{kV}$; scan axis gonio; step size $0.0013 \mathrm{~nm}$; time per step $96 \mathrm{~s}$. The results were evaluated using the software HighScore plus. The semi-quantitave analysis was only carried out due to the possible amorphous content in the samples.

\subsection{Interfacial zone characterization - SEM-EDX}

The Zeiss Evo LS 10 scanning electron microscope with EDX analysis was used for the characterization of the interfacial zone. The samples were AABFS pastes $(w / s=0.36)$ reinforced with one yarn of basalt fibres. They were broken after $7 \mathrm{~d}$ and $28 \mathrm{~d}$ of hydration and excessive fibres were removed. These fragments were placed on the carbon tape, sputter coated with gold and analysed (accelerating voltage $10 \mathrm{kV}$; probe $100 \mathrm{pA}$ ).

\section{RESULTS AND DISCUSSION}

\subsection{Loss of mass of the fibres}

The weight changes of the BFs due to the immersion in WG/SC and WG/SH solutions are shown in Figure 1. The immersion during the initial 14 days was accompanied by the most significant loss of mass and it slowed down thereafter (except for $12 \% \mathrm{Na}_{2} \mathrm{O}$ WG/SC mixture). It should be related to the formation of an insoluble or protective layer containing $\mathrm{Fe}^{3+}, \mathrm{Mg}^{2+}$ and $\mathrm{Ti}^{4+}$, as indicated in Y. V. Lipatovstudy. ${ }^{10}$ The dissolution rate of the fibres depends on factors like the diffusion rate or tendencies to re-precipitate a solid if the equilibrium is reached, as presented $i^{12}$, hence the oversaturation of the a immersion solution with particular ion can retard the further dissolution rate as well. This presumption was confirmed by the ICP-OES, as will be discussed later. There was a definite trend of the loss of mass dependence on the activator dosage - the higher activator dosage was the more significant loss of mass observed for WG/SC. The dependence of the loss of mass on the activator dosage was not so conclusive for
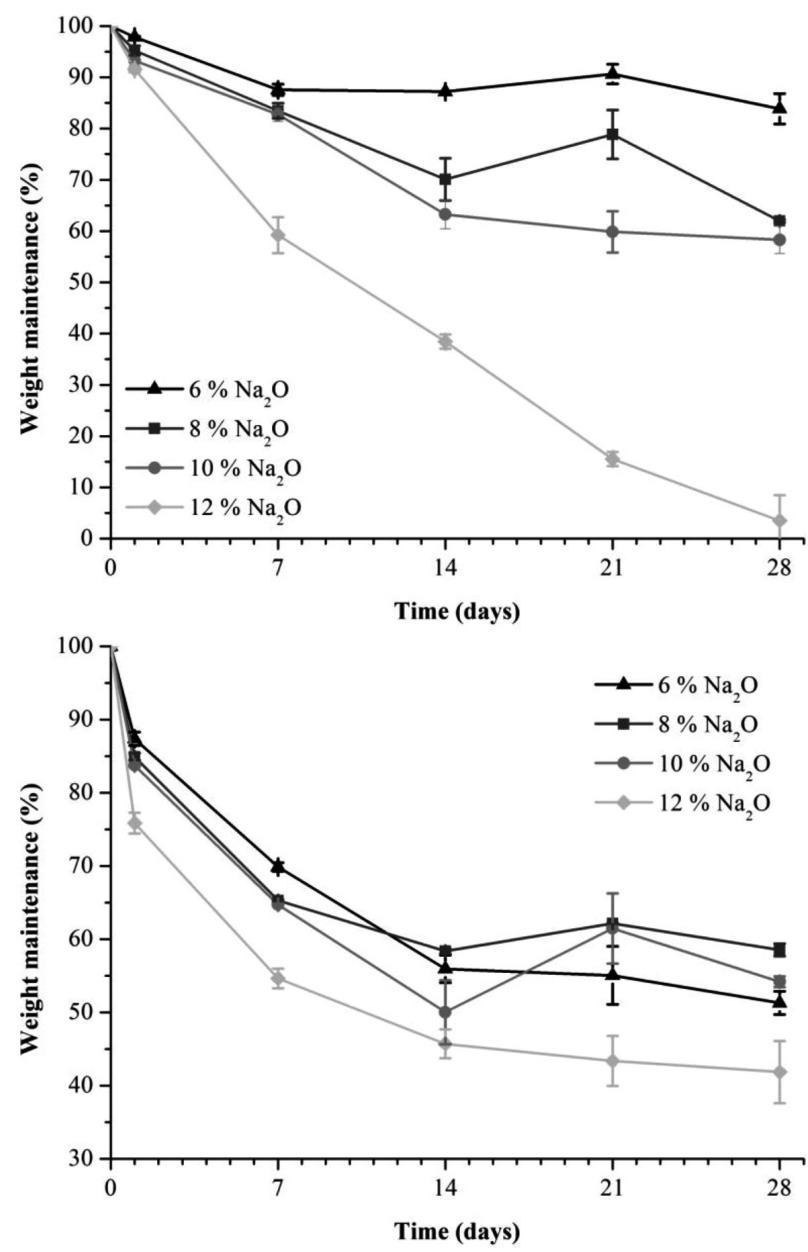

Figure 1: Dependence of BFs' weight maintenance on the time of immersion for activator dosages from: a) $6 \%$ to $12 \% \mathrm{Na}_{2} \mathrm{O}-\mathrm{WG} / \mathrm{SC}$, b) $\mathrm{WG} / \mathrm{SH}$ 


\section{P. HRUBÝ et al.: STABILITY OF BASALT-FIBRES REINFORCEMENT IN ALKALI-ACTIVATED SYSTEMS}

the WG/SH solutions. However, it seems that $\mathrm{WG} / \mathrm{SH}$ forms a more aggressive environment since the loss of mass was more intense for the $6-10 \% \mathrm{Na}_{2} \mathrm{O}$ dosages. The weight loss values for $6-10 \% \mathrm{Na}_{2} \mathrm{O}$ were $(16.1$, 38.1 and 41.7) \% for WG/SC, and 41.5, 45.8 and $48.7 \%$ for WG/SH solutions after $28 \mathrm{~d}$, respectively. These results are in a good correlation with those presented in J. J. Lee's paper ${ }^{11}$, where a weight loss of about $40 \%$ when immersed in $10 \% \mathrm{NaOH}$ for 80 days at a laboratory temperature was stated. H. Funke et al. ${ }^{13}$ stated a lower weight loss of BFs due to the leaching in $2-\mathrm{M} \mathrm{NaOH}$ at a laboratory temperature for $28 \mathrm{~d}$.

\subsection{Loss of tensile strength of the fibres}

The results obtained were expressed as tensile strength maintenance (comparison with the reference without leaching) after the leaching in WG/SC and WG/SH solutions and can be seen in Figure 2. The most significant deterioration of the tensile strength was noticed during the first $24 \mathrm{~h}$ (reduction of tensile strength to: $(33.9,45.1,20.7$ and 17.2) \% against the reference for 6-12 $\% \mathrm{Na}_{2} \mathrm{O}$ ) and continued up to $7 \mathrm{~d}$. Still, the simultaneous deterioration continued up to $28 \mathrm{~d}$, when none or very low remaining tensile strengths were measured $\left(2.1 \%\right.$ for $\left.6 \% \mathrm{Na}_{2} \mathrm{O}\right)$ in the case of the
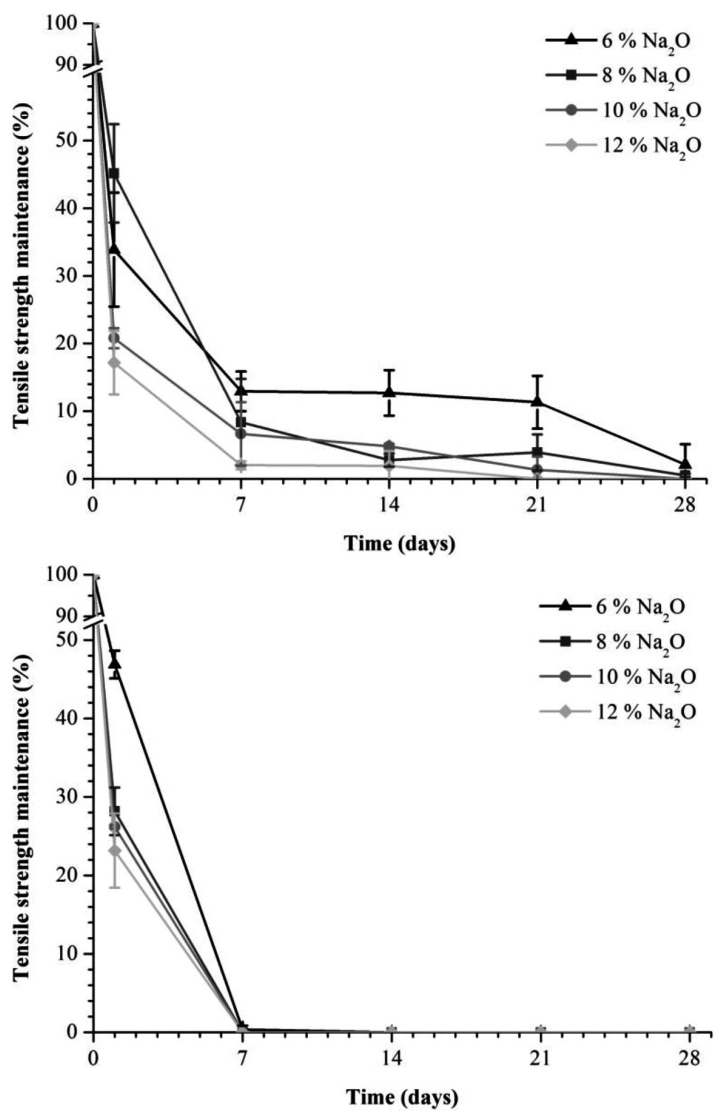

Figure 2: Dependence of BFs' tensile strength maintenance on the time of immersion for activator dosages from: a) 6 to $12 \% \mathrm{Na}_{2} \mathrm{O}-$ WG/SC, b) WG/SH
WG/SC solutions. There is a good correlation with the results obtained from the loss of mass testing, because the increase of the activator dosage led to a worsening of the remaining tensile strength too. It should be born in mind, that the loss of mass almost stopped within the standard deviations (6-10\% Na $2 \mathrm{O})$ after $21 \mathrm{~d}$; however, the loss of tensile strength continued thereafter. This is related to the formation of some precipitates on the surface of the fibres (confirmed using the XRD), which became ineffective for the tension carrying, as also stated $\mathrm{in}^{11}$. From the long-time point of view, a considerably more aggressive environment was formed using the WG/SH solutions, since none of the tensile strength could have been measured due to the advanced disintegration of the samples after $7 \mathrm{~d}$ and thereafter. Thus, the only ones which could be measured were the ones after $1 \mathrm{~d}$ of leaching $(46.9,28.2,26.2$ and 23.2) \% for $\left(6,8,10\right.$ and 12) $\% \mathrm{Na}_{2} \mathrm{O}$, respectively). It seems that the instability of the $\mathrm{BF}$ in the WG/SH solutions originates from the high dissociation constant of the hydroxyl ions, as stated in J. J. Lee et al. ${ }^{11}$, who also stated that the immersion of $\mathrm{BF}$ in saturated $\mathrm{Ca}(\mathrm{OH})_{2}$ had not been accompanied by a significant loss of mass but a rapid deterioration of the tensile strength was observed. The deterioration of the tensile properties was also stated in ${ }^{7}$ and $^{8}$.

\subsection{Chemical composition changes}

\subsubsection{ICP-OES}

The dissolution of the fibres should be related to the release of the main constituents into the immersion solutions, and thus with the increase of their concentration in the solutions. The concentration changes of $\mathrm{Al}$, $\mathrm{Fe}, \mathrm{Ca}$ and $\mathrm{Mg}$ were analysed with regard to the composition of the fibres, as well as the potential application in the AAS. The dependence of the concentration changes of chosen analytes for $6-12 \% \mathrm{Na}_{2} \mathrm{O}$ WG/SC and WG/SH solutions are shown in Figures 3 and $\mathbf{4}$, respectively. First, it should be mentioned that all the analysed elements were present in the initial solution before the leaching took place. It can be assumed that the concentration increase of those elements was related to the dissolution of the fibres. The background for the ICP-OES measurements was water.

More clear and persuasive results were obtained for the WG/SC solutions. The higher the activator dosage (6-12 \% $\quad \mathrm{Na}_{2} \mathrm{O}$ ) was, the more intense was the dissolution process of the fibres (the increase of the concentration of analytes in the immersion solution). The general trend can be described as follows. The concentration of elements simultaneously increases with the time of immersion up to certain concentration, but after that a gradual decrease was observed in most cases. This can be explained by the simultaneous dissolution of the fibres until the chemical equilibrium was reached, followed by the oversaturation of the solution with some 
P. HRUBÝ et al.: STABILITY OF BASALT-FIBRES REINFORCEMENT IN ALKALI-ACTIVATED SYSTEMS
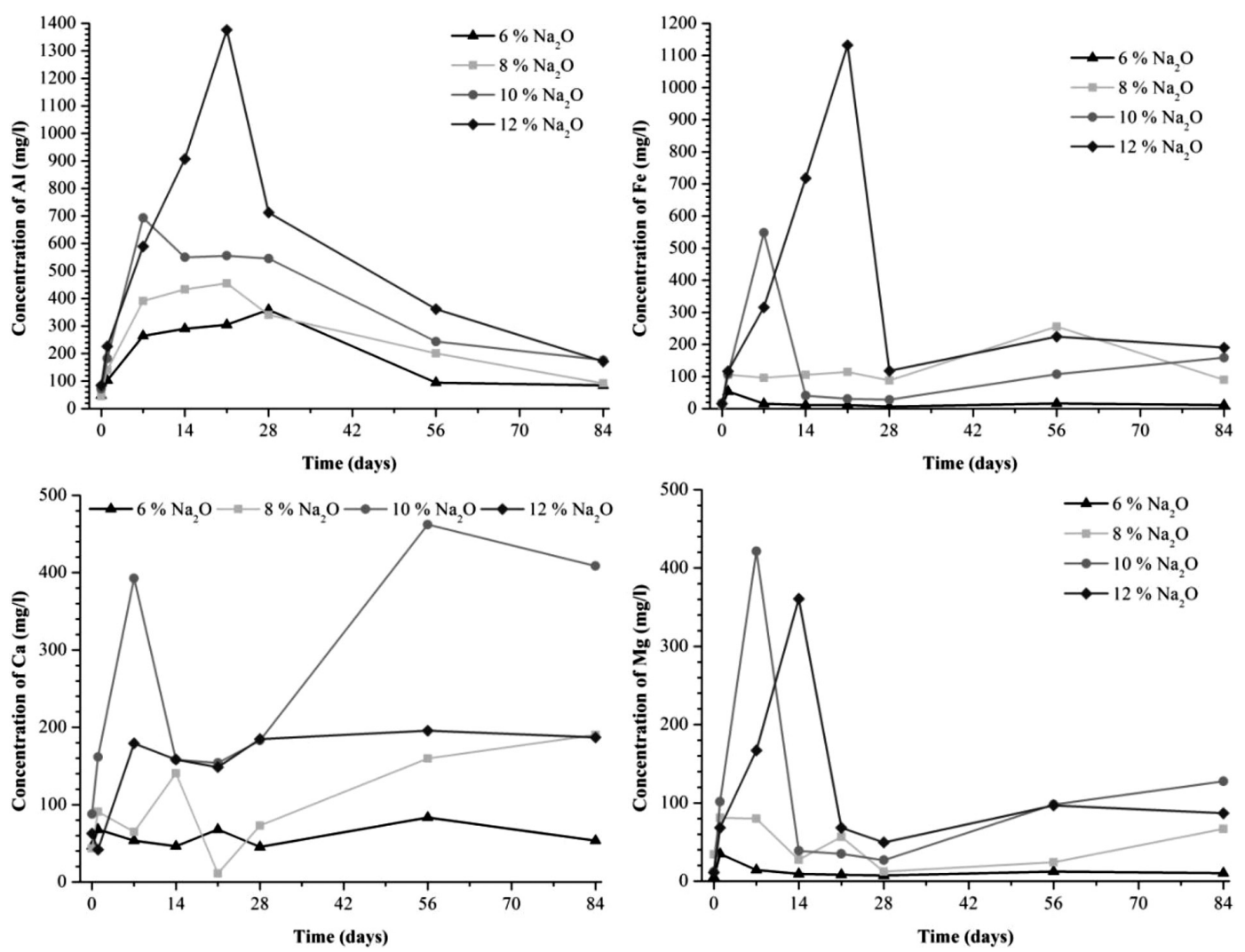

Figure 3: Chosen elements concentration development as a function of activator dosage and time of immersion of BFs in WG/SC solutions at $60{ }^{\circ} \mathrm{C}$
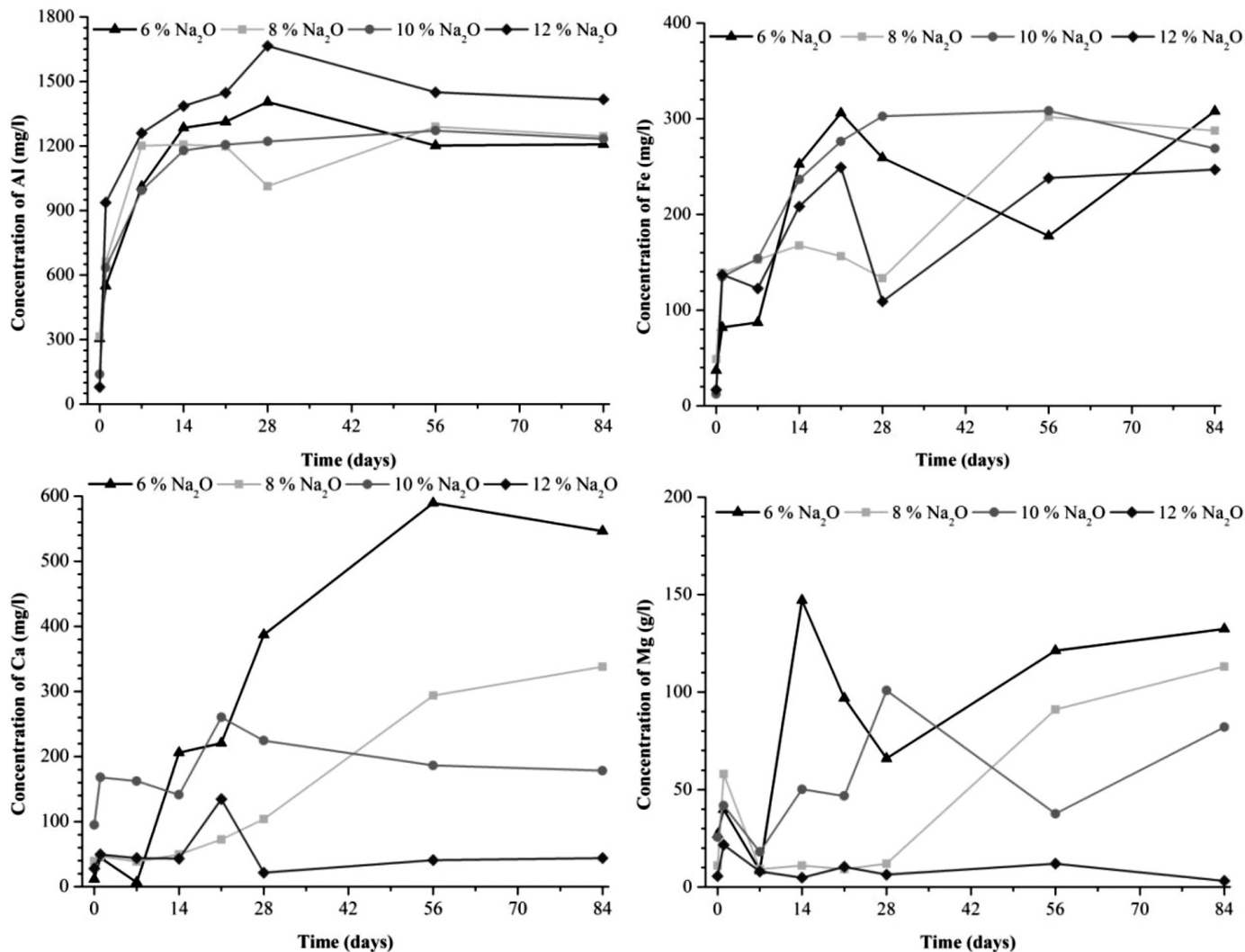

Figure 4: Chosen elements concentration development as a function of activator dosage and time of immersion of BFs in WG/SH solutions at $60{ }^{\circ} \mathrm{C}$ 


\section{P. HRUBÝ et al.: STABILITY OF BASALT-FIBRES REINFORCEMENT IN ALKALI-ACTIVATED SYSTEMS}

elements and ended with the precipitation/recrystallization of the least-soluble component (e.g. $\mathrm{CaCO}_{3}$ ). The comparison with the loss of mass results brings useful information such as the results of the $\mathrm{Al}$ concentration. A significant loss of mass was observed up to $14 \mathrm{~d}$, the ICP-OES validated this with the most significant increase of $\mathrm{Al}$ concentration in the immersion solution also up to $14 \mathrm{~d}$ for $6-10 \% \mathrm{Na}_{2} \mathrm{O}$. Moreover, the immersion in $12 \% \mathrm{Na}_{2} \mathrm{O}$ WG/SC was accompanied by the highest loss of mass, which continued up to $28 \mathrm{~d}$, which is the same trend as was observed for the $\mathrm{Al}$ concentration increase in the immersion solution. A positive effect of $\mathrm{Mg}$ or $\mathrm{Fe}$ presence on the formation ${ }^{10}$ of the stable layer was not confirmed, since the increase of their concentration immersion solution was also observed in the corresponding period of leaching.

The results obtained for the WG/SH solutions were not so definite, still they confirmed that WG/SH forms a more aggressive environment for the fibres and their dissolution is more intense (a larger amount of $\mathrm{Al}$ and $\mathrm{Fe}$ leached). Another difference lies in the fact that there are no signs of recrystallization or precipitation of the elements from the solution (please refer to the $\mathrm{Al}$ concentration change - the concentration simultaneously increases up to $14 \mathrm{~d}$ of immersion and almost stops after that; it indicates that all the $\mathrm{Al}$ is released from the fibres). A general trend of analytes concentration changes was also different. In the majority cases $(\mathrm{Mg}$, $\mathrm{Ca}, \mathrm{Fe}$ ) the increase of the activator dosage led to a lower increase of concentration in the immersion solution, but more intense as well at some point (Al). The solid-state compounds that precipitated in the solutions were subjected to XRD analysis and the presence of sodium carbonate in two modifications (low temperature - $91 \%$ and high temperature $-2 \%$ ), Pirssonite (6\%) and some aluminate silicate hydrate $(1 \%)$ for WG/SC solutions and sodium silicate $(63 \%)$ along with sodium carbonate (37\%) in the case of the WG/SH solutions were detected.

These results seem to be unsatisfactory, but a real AAS would include slag as well, thus the concentration of $\mathrm{Ca}, \mathrm{Al}, \mathrm{Fe}$ or $\mathrm{Mg}$ in the pore solution would be higher due to the slag dissolution, which should retard any further dissolution of the fibres. Another factor influencing the dissolution rate is the $\mathrm{pH}$, which would also be lower in real systems. This was also affirmed by the SEM-EDX analysis of the BF in the AABFS paste, where no signs of such a rapid dissolution of the $B F$ were noticed.

\subsubsection{XPS and XRD}

The chemical composition of the BF was determined using XPS after $28 \mathrm{~d}$ of treatment under alkaline conditions at elevated temperatures. The analysed samples were $10 \% \mathrm{Na}_{2} \mathrm{O} \mathrm{WG} / \mathrm{SC}$ and $\mathrm{WG} / \mathrm{SH}$ solutions. A special emphasis was towards the specification of the oxidation state of the present iron because of its significant influence on the dissolution resistance. The monovalent and divalent iron cations have a lower bonding energy to the glassy structure; hence they are more extensively and rapidly exchanged from the surface of the fibres than the trivalent cations. Ferric ions act as intermediates and favour the formation of the glassy structure, due to the smaller ionic radius over the $\mathrm{Fe}^{2+}$, as more discussed in my detail by T. Förster et al. ${ }^{12}$. Ferrous and ferric compounds were calculated by the multiplet peaks fitting of a high-resolution $2 \mathrm{p}_{3 / 2}$ spectra envelope by the Gupta and Sen model. ${ }^{14}$

The presumptions of better resistance of $\mathrm{Fe}^{3+}$ over the $\mathrm{Fe}^{2+}$ against the dissolution was not fully confirmed. The immersion in $10 \% \mathrm{Na}_{2} \mathrm{O} \mathrm{WG} / \mathrm{SH}$ was related to complete the dissolution of the iron from the fibre surfaces since the Fe $2 p$ photoelectric peak between 710.6-711.2 eV ${ }^{15}$ was not detected (Figure 5). The WG/SC solution with the same activator dosage forms less aggressive environments. The presence of iron in both oxidation states was observed $\left(\mathrm{Fe}^{3+}\right.$ at 60.5 at. \%; $\mathrm{Fe}^{2+}$ at 39.5 at. \%) along with $\mathrm{Al} 2 \mathrm{~s}$ and $\mathrm{Al} 2 \mathrm{p}$ photoelectric peaks, which were not detected for samples leached in WG/SH (the fact of total Al releasing from the fibres was also predicted based on the ICP-OES). It indicates that the dissolution of the glassy structure in the WG/SC solution proceeds to a lower extent than in the case of WG/SH. The Si 2 s and Si 2 p photoelectric peaks were detected for both samples.

$\mathrm{BF}$ samples after the immersion were subjected to the XRD as well. The immersion in $10 \% \mathrm{Na}_{2} \mathrm{O}$ WG/SC was accompanied by the formation of calcium carbonate along with the amorphous hump. In the case of the WG/SH solution the presence of an alumina-silicate compound containing $\mathrm{Na}, \mathrm{Ca}$ and $\mathrm{Mg}$ without an exact stoichiometry was detected.

\subsubsection{Interfacial zone characterization}

The formation of the transition zone as well as the quality of the adhesion between the matrix and the BFs

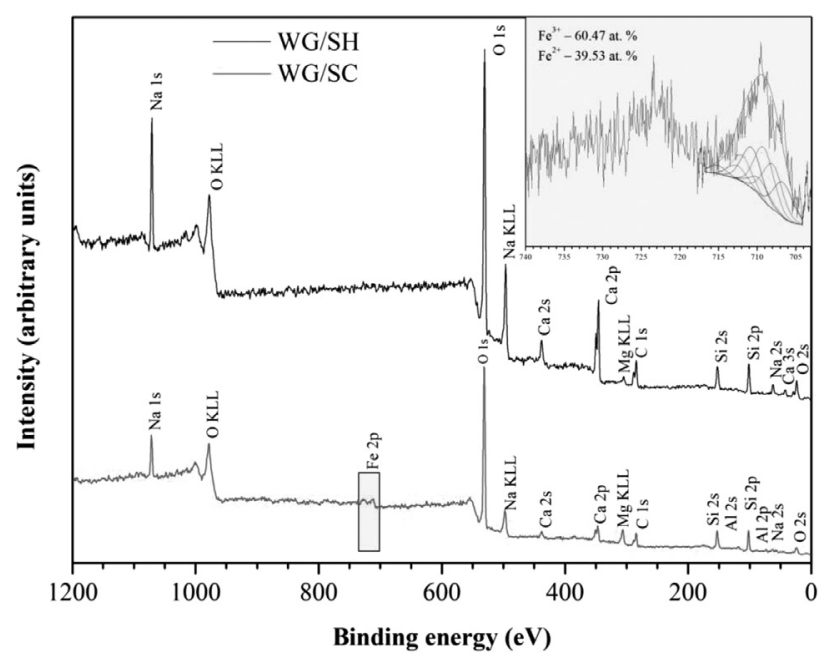

Figure 5: Results of XPS for BFs after the immersion in $10 \% \mathrm{Na}_{2} \mathrm{O}$ $\mathrm{WG} / \mathrm{SC}$ and WG/SH solutions up to $28 \mathrm{~d}$ at $60{ }^{\circ} \mathrm{C}$ 
are crucial for the reinforcement to be effective, and thus their further characterization was made. Very poor quality adhesion was achieved in the case of the $10 \%$ $\mathrm{Na}_{2} \mathrm{O}$ WG/SC system since the SEM images (Figure 6) showed relatively smooth surfaces of pastes under the fibres. Furthermore, the core of the fibres remained unattached by any paste fragments, as would be expected if some sort of interaction had taken place. The signs of significant degradation were not observed. Some sort of interaction was noticed after $7 \mathrm{~d}$ in case of the $10 \%$ $\mathrm{Na}_{2} \mathrm{O}$ WG/SH (Figure 7), where the presence of many attached paste fragments was detected (EDS analysis showed that the composition agreed with the composition of the surrounding matrix); however, this effect was no longer visible after $28 \mathrm{~d}$. Thus, it was perhaps related only to the slightly more etched surface (WG/SH systems have an higher initial $\mathrm{pH}$ ) of the fibres accompanied by the higher interaction with the matrix during the initial period. The fact that no chemical interactions between the BFs and the AAS (based on fly ash) were formed, was also stated in ${ }^{16}$.

The major hydration product for both tested AASs was $\mathrm{C}-\mathrm{A}-\mathrm{S}-\mathrm{H}$ gel with the $\mathrm{Ca} / \mathrm{Si}$ molar ratio of about
0.9-1 and the $\mathrm{Al} / \mathrm{Si}$ ratio of about 0.2. The composition of transition zone (1-50 $\mu \mathrm{m}$ from the fibres) for the WG/SH system was quite like the reference matrix far from the fibres (at least $3 \mathrm{~mm}$ ), but with some minor changes of $\mathrm{Ca} / \mathrm{Si}$ ratios. Still, it is likely the place with a lower degree of hydration than with other hydration products. This was confirmed by the elimination of the composition differences after $28 \mathrm{~d}$. The composition of the hydration products in the zone surrounding the fibres (less than $1 \mu \mathrm{m}$ ) was influenced by the BF composition due to the interaction volume at the chosen accelerated voltage, so there were some minor nuances in the composition, but no major influence can be attributed to them.

\section{CONCLUSIONS}

The applicability of the basalt fibres as reinforcing materials to the AAS was studied through various experiments, with the goal to determine their durability under the conditions simulating a highly alkaline environment like the one in the AAS matrix. The following conclusions were made:
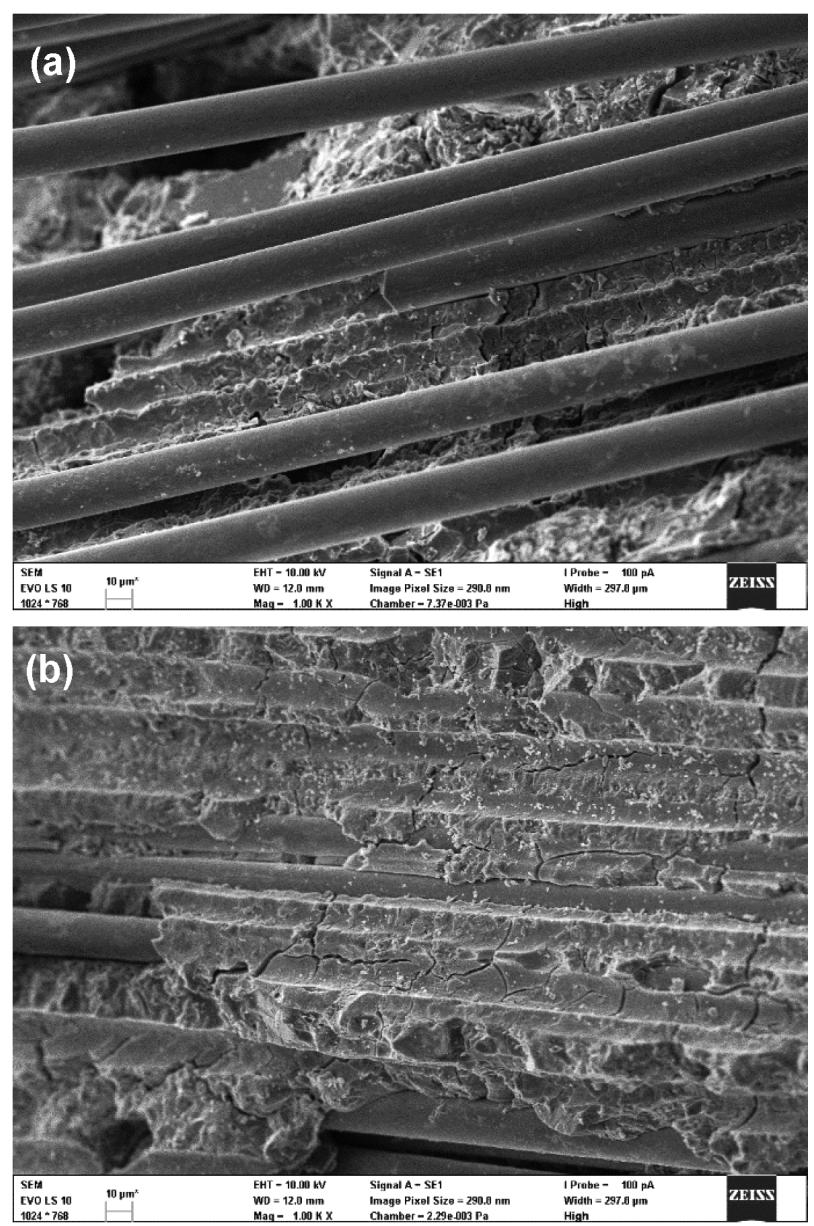

Figure 6: SEM images showing the fibre/matrix interfacial zone microstructure of WG/SC $10 \% \mathrm{Na}_{2} \mathrm{O}$ activated system after: a) $7 \mathrm{~d}$ and b) $28 \mathrm{~d}$ of hydration
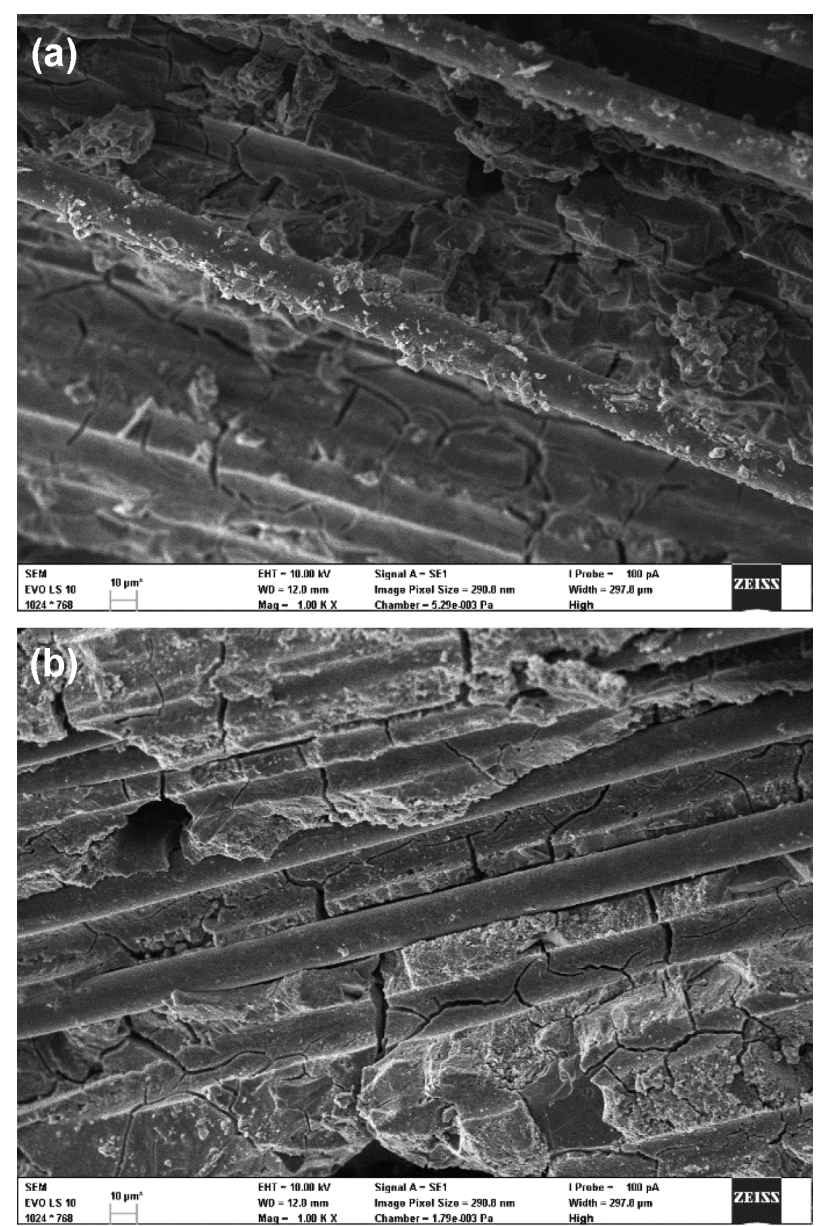

Figure 7: SEM images showing the fibre/matrix interfacial zone microstructure of WG/SH $10 \% \mathrm{Na}_{2} \mathrm{O}$ activated system after: a) $7 \mathrm{~d}$ and b) $28 \mathrm{~d}$ of hydration 


\section{P. HRUBÝ et al.: STABILITY OF BASALT-FIBRES REINFORCEMENT IN ALKALI-ACTIVATED SYSTEMS}

- Immersion of $\mathrm{BF}$ in 6-12\% $\mathrm{Na}_{2} \mathrm{O} \mathrm{WG} / \mathrm{SC}$ and $\mathrm{WG} / \mathrm{SH}$ solutions at $60{ }^{\circ} \mathrm{C}$ caused the dissolution of the fibres.

- A significant loss of mass of the fibres and the deterioration of the tensile strength were observed after the leaching of the $\mathrm{BF}$ in various solutions.

- The WG/SH solutions form a more aggressive environment, as can be seen from the results of the XPS, and others as well.

- No signs of quality adhesion or chemical interaction between the BF and AAS matrix were observed.

- Further research of the BFs' behaviour in these systems is necessary for their successful utilization as reinforcing material in various systems based on the alkali activation of blast furnace slag or various types of ashes. This research should focus especially on the possibilities of the surface coatings utilization on the basalt fibres, which could help to protect the core of fibres against the highly aggressive alkaline environment, such as the one in the AAS.

\section{Acknowledgement}

This outcome was achieved with the financial support by the project of specific research FCH-S-18-5194 and FCH/FSI-J-19-5794.

\section{REFERENCES}

${ }^{1}$ J. L. Provis, J. S. J. van Deventer, Alkali activated materials, $1^{\text {st }}$ ed. Springer, London 2014, 388, doi:10.1007/978-94-007-7672-2

${ }^{2}$ F. Pacheco-Torgal, Z. Abdollahnejad, A. F. Camões, M. Jamshidi, Y. Ding, Durability of alkali-activated binders: A clear advantage over Portland cement or an unproven issue?, Construction and Building Materials, 30 (2012), 400-405, doi:10.1016/j.conbuildmat.2011. 12.017

${ }^{3}$ P. Duxson, J. L. Provis, G. C. Lukey, J. S. J. van Deventer, The role of inorganic polymer technology in the development of 'green concrete', Cement and Concrete Research, 37, (2007) 12 , 1590-1597, doi:10.1016/j.cemconres.2007.08.018

${ }^{4}$ V. Dhand, G. Mittal, K. Y. Rhee, S. J. Park, D. Hui, A short review on basalt fiber reinforced polymer composites, Composites Part B: Engineering, 73, (2015) 12, 166-180, doi:10.1016/j.compositesb. 2014.12.01
${ }^{5}$ K. Singha, A short review on basalt fiber, International Journal of Textile Science, (2012), 19-28, doi:10.5923/j.textile.20120104.02

${ }^{6}$ J. Sim, C. Park, D. Y. Moon, S. J. Park, D. Hui, Characteristics of basalt fiber as a strengthening material for concrete structures, Composites Part B: Engineering, 36, (2005) 6-7, 504-512, doi:10.1016/j.compositesb.2005.02.002

${ }^{7}$ B. Wei, H. Cao, S. Song, S. J. Park, D. Hui, Tensile behaviour contrast of basalt and glass fibers after chemical treatment, Composites Part B: Engineering, 31 (2010) 9, 4244-4250, doi:10.1016/j.matdes.2010.04.009

${ }^{8}$ S. Ying, X. Zhou, S. Song, S. J. Park, D. Hui, Chemical and thermal resistance of basalt fiber in inclement environments, Journal of Wuhan University of Technology-Mater. Sci. Ed, 28, (2013) 3, 560-565, doi:10.1007/s11595-013-0731-4

${ }^{9}$ V. A. Rybin, A. V. Utkin, N. I. Baklanova, Alkali resistance, microstructural and mechanical performance of zirconia-coated basalt fibers, Cement and Concrete Research, 53 (2013), 1-8, doi:10.1016/j.cemconres.2013.06.002

${ }^{10}$ Y. V. Lipatov, S. I. Gutnikov, M. S. Manylov, E. S. Zhukovskaya, B. I. Lazoryak, High alkali-resistant basalt fiber for reinforcing concrete, Cement and Concrete Research, 73, (2015), 60-66, doi:10.1016/j.matdes.2015.02.022

${ }^{11}$ J. J. Lee, J. Song, H. Kim, E. S. Zhukovskaya, B. I. Lazoryak, Chemical stability of basalt fiber in alkaline solution, Fibers and Polymers, 15, (2014) 11, 2329-2334, doi:10.1007/s12221-0142329-7

${ }^{12}$ T. Förster, C. Scheffler, E. Mäder, G. Heinrich, D. A. Jesson, J. F. Watts, Dissolution behaviour of model basalt fibres studied by surface analysis methods, Applied Surface Science, 322, (2014) 11, 78-84, doi:10.1016/j.apsusc.2014.10.058

${ }^{13}$ H. Funke, S. Gelbrich, L. Kroll, G. Heinrich, D. A. Jesson, J. F. Watts, The Durability and Performance of Short Fibers for a Newly Developed Alkali-Activated Binder, Fibers, 4, (2016) 4, 78-84, doi:10.3390/fib4010011

${ }^{14}$ A. P. Grosvenor, B. A. Kobe, M. C. Biesinger, N. S. McIntyre, D. A. Jesson, J. F. Watts. Investigation of multiplet splitting of Fe 2p XPS spectra and bonding in iron compounds, Surface and Interface Analysis, 36, (2004) 12, 1564-1574, doi:10.1002/sia.1984

${ }^{15}$ T. Yamashita, P. Hayes, M. C. Biesinger, N. S. McIntyre, D. A. Jesson, J. F. Watts, Analysis of XPS spectra of $\mathrm{Fe}_{2}$ and $\mathrm{Fe}_{3}$ ions in oxide materials, Applied Surface Science, 254, (2008) 8, 2441-2449, doi:10.1016/j.apsusc.2007.09.063

${ }^{16} \mathrm{~W}$. Li, J. Xu, Impact characterization of basalt fiber reinforced geopolymeric concrete using a 100-mm-diameter split Hopkinson pressure bar, Materials Science and Engineering: A, 513-514, (2009) 145-153, doi:10.1016/j.msea.2009.02.033 